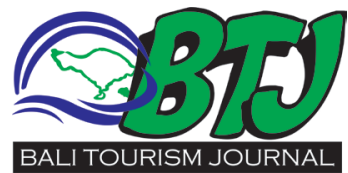

\section{Bali Mandara Hospital; Noble Purpose, Controversial results}

\author{
Ida Ayu Adi Trisnawathi ${ }^{1}$
}

${ }^{1}$ Kopiku Roasters

E-mail: song.of.eternity@gmail. com

\section{Editor:}

Ida Bagus Ngurah Tri Pramana

Received: 29 0ctober 2017 Accepted: 1 November 2017 Published: 3 November 2017

\title{
ABSTRACT
}

As a commitment to improve health services in Bali, the Bali Provincial Government built Bali Mandara International Hospital. The hospital is to be expected becoming the best hospital in Bali. aimed to help the poor family to get the best health care. can be directed to become a medical tourism destination. However, There was some commotion on the employee's recruitment process of Bali Mandara Hospital, where violations allegedly occurred in the process of recruitment of new employees, especially in recruiting non-government contract workers. The demonstration of Sanur community also occurred on 0ctober $28^{\text {th }}, 2017$ to demand justice and transparency in the recruitment of employees at the newly built hospital where they were promised to get ten percent quota for the job vacancies. although facing many problems, the Hospital keep operating until now. The employee recruitment system that is considered not transparent, cause the noble goal of Bali Provincial Government to improve the community's health service through Bali Mandara Hospital is not well conveyed. Corruption, Collusion and nepotism practices that are still firmly rooted in some agencies make public's trust toward Government become low. in addition, the public is expected to be more careful in receiving information. Because if the information is misleading, it could result in the disadvantage of many parties.

Keyword: Bali Mandara Hospital, Bali Provincial Government, Demonstration, Sanur

Cite This Article: Ida Ayu Adi Trisnawathi, Bali Mandara Hospital; Noble Purpose, Controversial result (BTJ)2017, 1 (1): 30-34

\section{INTRODUCTION}

As a commitment to improve health services in Bali, the Bali Provincial Government built Bali Mandara International Hospital (RSBM). ${ }^{1}$ The hospital is built on the land owned by the Bali Provincial Government which is strategically located on By Pass Ngurah Rai, Sanur. ${ }^{2}$

The hospital is to be expected becoming the best hospital in Bali. Governor of Bali Made Mangku Pastika affirmed that the construction of Bali Mandara international hospital would be aimed to help the poor family to get the best health care. Pastika also reiterated that best facilities not only for rich people but the poor also have rights, and the government must facilitate them.

Not only to accommodate patients from the underprivileged, with international standard facilities but also this hospital according to Pastika can be directed to become a medical tourism destination. The plan has received support from the central government, in which Government of Bali states their readiness to provide international standard medical personnel and facilities. "This might be something to offer that is difficult for other areas to follow and this will be our advantage," said Pastika. ${ }^{1}$

The governor even instructed that the construction of this hospital must be accelerated thus it may be inaugurated in April 2017. Pastika also plans to build a special clinic for cancer patients adjacent to Bali Mandara Hospital, considering the number of cancer patients from year to year tends to increase. ${ }^{4}$

Meanwhile, head of Bali Provincial Health Office, dr Ketut Suarjaya said the operation of RS Bali Mandara is planned to be officially opened during the commemoration of the 59th anniversary of the Bali Provincial Government on August 14, 2017. Built on 2.5 hectares of land owned by the Bali Provincial Government, Bali Mandara Hospital with international standard directed to become Hospital Tourism. The Hospital located at Jalan Bypass Ngurah Rai Sanur, South Denpasar is also preparing Class III services for patients using BPJS facilities and alternative medicine.

Bali Mandara Hospital was built for 450 days, from September $11^{\text {th }}, 2015$ to December $3^{\text {rd }}, 2016$. while medical and non-medical personnel who will be involved in operational of Bali Mandara Hospital will reach 520 people. The details are 56 general practitioners and specialists, 228 nursing staff, 91 other health workers, 22 pharmacists and pharmacist assistants, and 123 non-health workers. ${ }^{5}$

\section{CONTROVERSY}

There was some commotion on the employee's 


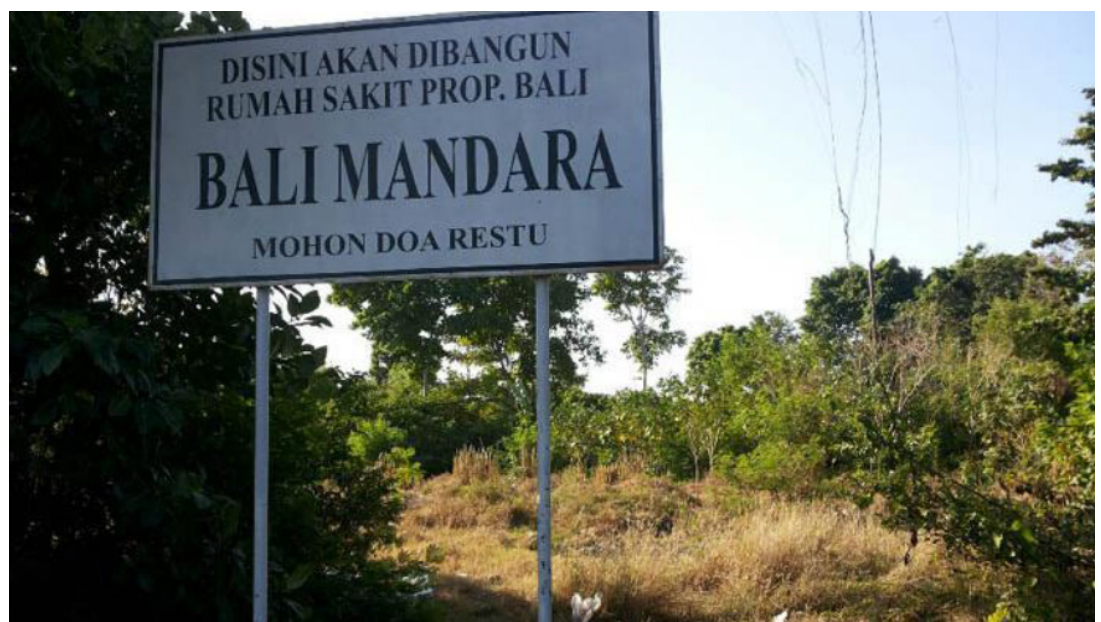

Figure. 1 The hospital is built on the land owned by the Bali Provincial Government which is strategically located on By Pass Ngurah Rai, Sanur $^{3}$

\section{Mellysa Kowara}

Apr 8 at 11:26am - 8

\section{Super shock melihat pengumuman hasil seleksi Rumah Sakit Bali Mandara pagi ini. Saya mendaftar pada bagian ilmu kesehatan masyarakat berbekal IPK 3.87, pengalaman kerja, pengalaman pelatihan dan seminar, kemampuan bahasa inggris IELTS yang sudah dikategorikan competent user dan pengalaman organisasi. Pada saat tes tulis menggunakan CAT, hasil tes saya peringkat 2 pada seluruh pelamar IImu Kesehatan Masyarakat dengan total nilai 394. Pada}

Figure. 2 a Facebook user uploads a status whose content doubts the recruitment process goes transparently ${ }^{7}$

recruitment process of Bali Mandara Hospital, where violations allegedly occurred in the process of recruitment of new employees, especially in recruiting non-government contract workers. The issue arises after a Facebook user uploads a status whose content doubts the recruitment process goes transparently and reports it to the Ombudsman. ${ }^{6}$ It was said employee acceptance system is through Computer Assisted Test (CAT) and Interview session. Where from the selection results, mentioned many applicants who have a high score in CAT, failed in the interview session.

The process of recruitment of non-government contract workers is not transparent, thus making the community question the recruitment process to the Bali provincial government through the parliament of Bali. ${ }^{8}$ Since the complaint to the parliament of
Bali, until Monday (17/4), there have been at least 10 cases received.

The Golkar Party politician from Buleleng Regency who is also a member of the Bali Regional House of Representatives, Ida Gede Komang Kresna Budi said that the selection committee team must suspend the process of the test whether to the participants who passed the written test or interview. On the contrary, from his view, the selection committee continue the process. it is clearly contrary to the agreement during a working meeting with Governor Made Mangku Pastika, that during the time of the complaint the selection process must be temporarily suspended, "he added. ${ }^{9}$

Although there are problems during the recruitment process of Bali Mandara Hospital, yet still on the investigation, the selection process is even continued. In the end, Bali Hospital is ready to be inaugurated on 28 October 2017

A few days toward the inauguration of RSBM, on October 28th, 2017, another commotion emerged. Some community leaders, village officials, and leaders of the Sanur Development Foundation or Yayasan Pembangunan Sanur (YPS) visited the Bali Mandara Hospital on Tuesday (24/10) at around $12.00 \mathrm{pm}$. They went to Bali Mandara Hospital, after the Deputy Governor of Bali Ketut Sudikerta canceled the meeting which has been scheduled for YPS Office at 11:00 pm. The group consisted of YPS Chairman, Ida Bagus Gede Sidharta Putra, vice chairman of YPS, I Gusti Alit Kencana, community leaders and Prajuru from Sanur, together with Vice Chairman of Denpasar Parliament from Golkar faction Wayan Mariyana Wandira. They were received directly by The acted as Director of Bali Mandara Hospital, dr Bagus Darmayasa. The purpose of the group's arrival is to demand the government's commitment, which previously promised to provide 10 percent of the roughly 500 workers at the Bali Mandara Hospital for Sanur's community. It is revealed from 500 recruitment workers for the Bali Mandara Hospital, only seven Sanur residents were accepted as a worker, with details of 3 locals and 4 immigrants who reside in Sanur. In fact, residents of Sanur promised to get a quota of 10 percent of the total workforce received at Bali Mandara Hospital.

As an act of disappointment, vice chairman of the YPS, Alit Kencana stated that they are going to mobilize a mass of 19,000 people to attend the launching event at Bali Mandara Hospital. The mass of 19,000 people came from various elements of the Sanur community, from traditional villages, banjars, Sekaa Teruna, to PKK. ${ }^{10}$

On the next day, Sanur Kauh's Village Head, I Made Ada met Bali governor, Made Mangku 
Pastika related to the demands of Sanur residents to have a quota of 10 percent of Sanur people can be accepted at Bali Mandara Hospital (26/10/2017). A spokesman for the Bali provincial government denied there is any promise that mentioned there would be 10 percent quota for Sanur residents can be accepted to be employees. In a closed meeting, at the meeting room of the governor's office were attended by Head of Health Office, Head of Empowerment and Village of Bali Provincial Government, Head of Bali's local employment agency and Head of PR of Bali Government, Dewa Gede Mahendra.

Mahendra explained that through this familyfriendly meeting, he appreciated the request of the people of Sanur. Regarding the information of 10 percent quota appointment for the people of Sanur, he said Bali Governor Made Mangku Pastika personally, and Bali Provincial Government has never promised to residents of Sanur given special quota related to the recruitment. However, the Provincial Government of Bali gives their appreciation to the citizens of Sanur by providing priority associated with the filling of 19 vacant formations. The formation includes the formation of 4 specialist doctors, six people with health Bachelor degree, six people with D3 health, seven people for non-health workers, four people for the driver, one person for laundry and two people for the building. Later Sanur residents will be given priority to fill the vacant position and must meet the requirements and competencies according to RSBM recruitment standards. ${ }^{11}$

\section{DEMONSTRATION}

The act of disappointment of Sanur community was proven during the inauguration of RSBM on Saturday, October $28^{\text {th }}, 2017$. Thousands of Sanur Residents dressed in traditional madya uniform with banners reading "Sanur citizens reject to be fooled" move from Mertasari Beach, Sanur, to Bali Mandara Hospital located on Jalan By Pass Ngurah Rai. They shouted yells in a rally ahead of the opening of Mandara Bali Regional Hospital (RSUD) to demand justice and transparency in the recruitment of employees at the newly built hospital. ${ }^{12}$

The masses that flooded the RSBM area also made the By Pass I Gusti Ngurah Rai traffic faltered during the action. One member of the Denpasar Parliament who is also a community figure leader of Sanur, IB Ketut Kiana, regretted the absence of the authorities. He said the authorities should meet the community and ensure that the Governor's pledge to receive 19 people as an employee on 2017 and 40 people more with the majority formation of a security guard in 2018 . The Hanura party politician from Geria Wanasari, Sanur explains why the Sanur people decided to the demonstration, thus that the public will understand.

"If only the authorities were willing to meet people on the Mertasari beach before the demonstration started, I guarantee there will be no demonstration to the hospital. The people of Sanur are well aware that the hospital belongs to the State and means the property of the people who need to be kept together."

Kiana added that it is necessary for every workplace or employment opened in one area, the surrounding community also entitled to enjoy it by providing employment opportunities. However, the reality from 280 applicants of Sanur community, there were only 3 people accepted as employees. Does it mean a mutual understanding? " $\mathrm{He}$ questioned

The coordinator of Sanur residents' demonstration who protested the launching of Bali Mandara Hospital (RSBM), Ida Bagus Gede Sidharta Putra, said that the demonstration was held to demand the government's promise to provide 10 percent vacancy at RSBM for Sanur residents. Ida Bagus Sidharta Putra also mentioned that there is a promise from the government to provide 10 percent acceptance of local workforce. A written promise of 10 percent of the domestic workforce was presented by the Bali Mandara Hospital socialization team to the residents when the Environmental Impact Analysis (EIA) process conducted before the hospital was built. While the contents of the letter, there is an agreement that the worker from Sanur will be prioritized to work in the hospital.

"So there is an agreement, and we have submitted to the Governor of Bali, of course, we now demand the promise, we submitted the name according to the formation required by the hospital and certainly follow its strict selection," said Sidharta Putra. ${ }^{14}$

There are 280 Sanur people who are proposed to fill the position at RSBM. It consists of professional workers who intended to fill jobs ranging from specialists, nurses to cleaning personnel. "There is already a statement from the provincial government to provide formation for the citizens of Sanur. But, we do not want to be fooled by promises, we demand a written pact. Because in fact, from 550 available positions in RSBM, they only accepted three people. "The 10 percent minimum priority we asked. If in the industry, we asked 40 percent more. If not met, we will continue this action, "he said.

The acted Director of Bali Mandara Hospital, Bagus Darmayasa meet the demonstrators after picked up by the demonstrator. He was also given the opportunity to speak in front of thousands of Sanur 


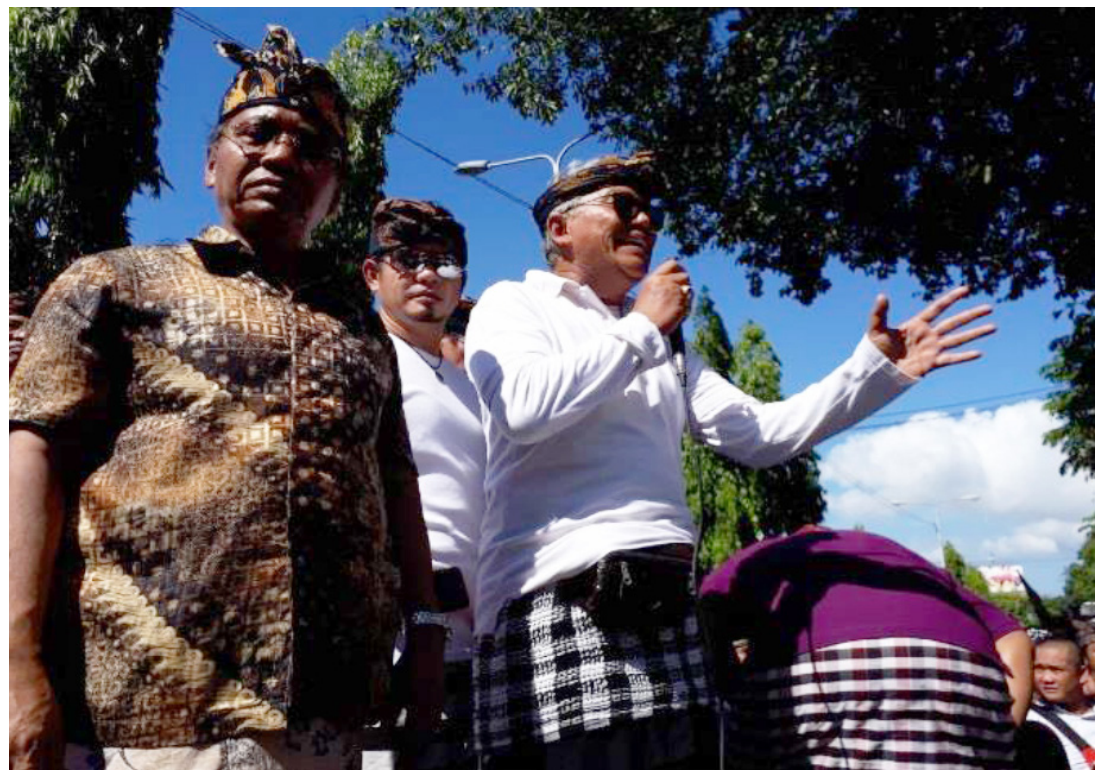

Figure. 3. The act of disappointment of Sanur community ${ }^{13}$

Society. However, he claimed to have no authority or whatsoever regarding to answer the demands of the Sanur community. "I do not have the authority to decide, the right to take the policy is from the Provincial Government of Bali, he only acted as instructed," said Darmayasa. ${ }^{12}$ The demonstration lasted until noon without any anarchic action, then the community dismissed after they finished their oration in front of RSBM.

\section{GOVERNOR'S RESPONSE}

Bali Governor Made Mangku Pastika said Bali Mandara Hospital remains open with no ceremonial event or launching ceremony, although the Sanur residents had demonstrated. He said, right in the middle of the day after thousands of residents of Sanur staged a demonstration, Pastika accompanied by Director of RSBM dr Bagus Dharmayasa and RSBM staff at that time held a prayer event.

After praying, then the Bali Mandara Hospital's sheath was opened. However, before the hospital veil is opened, all banners and congratulatory flowers have been removed. Pastika regretted the residents of Sanur on the Youth Pledge Day held a demonstration since the day before had been conducted meetings with local citizens.

"I wish there were no demonstration because it is a hospital, the hospital is one that cannot be demonstrated, it is completely wrong, I do not know exactly the rules. However it can be convicted. If people are protesting the hospital, it is the same as demonstrating the house of worship, thus why I remind them, "he said.

He added that the hospital also should not be protested because it may result in stress of medical personnel and health personnel. Thus it is not good. "I thought there are no more problems; I heard that they would gather in Mertasari to ask the governor to come in. If not satisfied, it would be a demonstration; I am sure they would not be satisfied if I came in. Finally, I ask dr Bagus not to launch, close the door, and just look what happened, "he said.

Pastika added, when the RSBM is opened, there is already a direct patient, a children who got a fever and two foreign tourists, and there is also an ambulance request. "If we do not accept it, then if the person is dead, whose responsibility is it?" he questioned.

Regarding the issue of allocation of 10 percent of workers at RSBM to the people of Sanur, according to him, it is not promised by a team from the provincial government who previously held a socialization for the construction of the hospital. But it is a request from the citizens of Sanur itself.

Previously, thousands of people of Sanur staged a demonstration in front of Bali Mandara Hospital. They insisted that 10 percent of the formation of labor in the Bali provincial hospital was realized.

"We are moving here because there is no written pact. We are tired of promises, what as promised yesterday, Our society wants certainty," said Chairman of the YPS, Ida Bagus Gede Sidharta Putra on the sidelines of the peaceful action. It will demand up to 10 percent, under consideration thus the residents of Sanur do not become a bystander in their region? "The number we demanded is for the welfare of the people of Sanur," he said. ${ }^{14}$

\section{CONCLUSION}

The employee recruitment system that is considered not transparent, cause the noble goal of Bali Provincial Government to improve the community's health service through Bali Mandara Hospital is not well conveyed. Corruption, Collusion and nepotism practices that are still firmly rooted in some agencies make public's trust toward Government become low. in addition, the public is expected to be more careful in receiving information. Because if the information is misleading, it could result in the disadvantage of many parties. 


\section{REFERENCES}

1. Press Release of Bali Provincial Government. GUBERNUR PASTIKA AJAK DEWAN TINJAU PEMBANGUNAN RS INTERNASIONAL BALI MANDARA. 2016. http://www. baliprov.go.id/id/GUBERNUR-PASTIKA-AJAK-DEWANTINIAU-PEMBANGUNAN-RS-INTERNASIONALBALI-MANDARA. Accessed on : Monday, 13 November 2017

2. Sandi EP.RS Bali Mandara Terbaik di Bali, Mangku Pastika: Bukan untuk Bule. Tribun Bali.2015. http://bali. tribunnews.com/2015/09/12/rs-bali-mandara-terbaik-dibali-mangku-pastik-bukan-untuk-bule

3. Zaenal. Bali Akan Miliki Rumah Sakit Provinsi. TribunBali.2014. http://bali.tribunnews.com/2014/08/05/ bali-akan-miliki-rumah-sakit-provinsi

4. Nur Aini.Pembangunan Dua Rumah Sakit di BaliDipercepat.AntaraNews.2016. http://nasional. republika.co.id/berita/nasional/daerah/16/04/09/ o5dcm4382-pembangunan-dua-rumah-sakit-di-balidipercepat

5. Nv.RS Bali Mandara Siapkan Kelas III.Nusa Bali.2017. http://www.nusabali.com/berita/10374/rs-bali-mandarasiapkan-kelas-iii

6. Wahyura AAGP.Tak Lolos Rekrutmen RS Bali Mandara, Mellysa Kowara Lapor Ombudsman.TribunBali.2017. http://bali.tribunnews.com/2017/04/11/tak-lolosrekrutmen-rs-bali-mandara-mellysa-kowara-laporombudsman.

7. Screenshot Facebook. Ada Apa dalam Seleksi Tenaga Kontrak RSUD Bali Mandara?.Suara Dewata.2017. https:// www.suaradewata.com/read/2017/04/09/201704090015/ Ada-Apa-dalam-Seleksi-Tenaga-Kontrak-RSUD-BaliMandara.html

8. Nv.Gubernur Minta Bukti Pelanggaran Rekrutmen Pegawai Kontrak RS Bali Mandara.NusaBali.2017. http:// www.nusabali.com/berita/12650/gubernur-mintabukti-pelanggaran-rekrutmen-pegawai-kontrak-rs-bali$\underline{\text { mandara }}$
9. Ada 10 Pengaduan Rekrutmen RSBaliMandara, Dewan Bali: Panitia Seleksi Kok Jalan Terus?. Berita Bali.2017. https:// www.beritabali.com/read/2017/04/19/201704190008/Ada10-Pengaduan-Rekrutmen-RS-Bali-Mandara-DewanBali-Panitia-Seleksi-Kok-Jalan-Terus.html

10. Nv.Warga Sanur Ancam Gerudug RS Bali Mandara. NusaBali.2017. http://www.nusabali.com/berita/20427/ warga-sanur-ancam-gerudug-rs-bali-mandara

11. Wahyura AAGP. Warga Sanur Merasa Dijanjikan Kuota 10 Persen Lowongan di RSBM, Pemprov Bali : Siapa Yang Janji?. TribunBali.2017. http://bali.tribunnews. com/2017/10/26/warga-sanur-merasa-dijanjikan-kuota10-persen-lowongan-di-rsbm-pemprov-bali-siapa-yangjanji

12. Widyaswara IWE. Begini Tuntutan Pendemo RS Bali Mandara, Koordinator Aksi: Kami Minta Hitam di Atas Putih!. Tribun Bali. 2017. http://bali.tribunnews. com/2017/10/29/begini-tuntutan-pendemo-rs-balimandara-koordinator-aksi-kami-minta-hitam-di-atasputih

13. Dokumentasi Foto Pribadi.2017

14. Anonymous.Seribuan Warga Adat Sanur Demo Rumah Sakit Bali Mandara. Viva News. 2017.http://www.viva. co.id/berita/nasional/971871-seribuan-warga-adat-sanurdemo-rumah-sakit-bali-mandara

15. Rhismawati NL. Gubernur Bali: RSBM dibuka tanpa ada "launching”.Antara News.2017 https://www.antaranews. com/berita/661738/gubernur-bali-rsbm-dibuka-tanpaada-launching

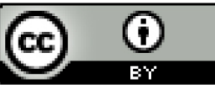

This work is licensed under a Creative Commons Attribution 